\title{
Allergy and related clinical symptoms among medical students and interns
}

\author{
Nahla Khamis Ibrahim ${ }^{1}$, Abeer Ali Alghamdi², Mayar Majed Almehmadi ${ }^{3}$, \\ Asma Abdulwahed Alzahrani ${ }^{4}$, Asraa Khairallah Turkistani ${ }^{5}$, Khalid Alghamdi ${ }^{6}$
}

\begin{abstract}
Objectives: To determine the prevalence, types, clinical presentations, triggers, and predictors of allergic disorders among medical students and interns at King Abdulaziz University (KAU), Jeddah, Saudi Arabia.

Methods: A cross-sectional design was used for this study in which 600 medical students and interns were selected by a multistage stratified random sampling. A validated, confidential, selfadministered questionnaire was used during 2016 / 2017. It asked about the previous diagnosis of allergic disorders, associated factors, types, clinical symptoms and the triggering allergenic. Descriptive \& inferential statistics were done and logistic regression analysis was conducted.

Results: The overall prevalence of diagnosed allergic disorder(s) among the participants was $36.2 \%$. The commonest types of allergy were skin $(33.8 \%)$ followed by respiratory $(29.5 \%)$ presentations. The most frequently reported allergenic triggers were the house dust $(45.6 \%)$ and smoke $(30.4 \%)$. The first allergy predictor was family history of allergic disorders $(\mathrm{aOR}=4.35,95 \% \mathrm{Cl}: 2.96-6.39)$, followed by female gender. Regarding the outcome of allergy on students' life, $16.1 \%$ occasionally missed classes, and $28.6 \%$ had sleep disturbance during allergic attacks.

Conclusion: Allergy represents an important problem among medical students and interns. Family history and female gender were the predictors of allergy. Skin and respiratory allergies were the most common types. House dust and smoke were the commonest allergenic triggers. Detection of allergens and management of cases of allergy among medical students and interns are needed. Education and conduction of awareness campaigns about allergy are needed.
\end{abstract}

KEYWORDS: Allergy, Clinical presentations, Predictors, Prevalence, Triggers.

doi: https://doi.org/10.12669/pjms.35.4.1281

How to cite this:

Ibrahim NK, Alghamdi AA, Almehmadi MM, Alzahrani AA, Turkistani AK, Alghamdi K. Allergy and related clinical symptoms among medical students and interns. Pak J Med Sci. 2019;35(4):1060-1065. doi: https://doi.org/10.12669/pjms.35.4.1281

This is an Open Access article distributed under the terms of the Creative Commons Attribution License (http://creativecommons.org/licenses/by/3.0), which permits unrestricted use, distribution, and reproduction in any medium, provided the original work is properly cited.

\section{INTRODUCTION}

Allergy is a widespread global public health problem. ${ }^{1}$ It has continuously escalating rates, and it can lead to serious complications. ${ }^{1,2}$ The etiology of allergy is due to interactions between both environmental factors, with the permissive genetic

\footnotetext{
Correspondence:

Nahla Khamis Ibrahim,

Department of Community Medicine, Faculty of Medicine

King Abdulaziz University, Jeddah, Saudi Arabia.

P.O Box: 42806, Postal code: 21551

Email: nahlakhamis@yahoo.com

* Received for Publication:

November 4, 2018

* Revision Received:

* Revision Accepted:

April 24, 2019

April 29, 2019
}

factors. ${ }^{3}$ Allergy is a hypersensitivity reaction in which the immune mechanism responds (by IgE antibody) to the environmental materials (allergen) that are normally considered harmless. ${ }^{4}$

Allergic disorders have multi-organ presentations such as allergic rhinitis, asthma, urticaria, eczema and anaphylaxis. ${ }^{1}$ They are eco-system related conditions, with variations in predictors, and triggering allergens from different countries. ${ }^{3}$ The increasing rates of allergy may be attributed to changes in the lifestyles and living conditions. ${ }^{2}$ Such increase is well recognized globally during the previous few decades. ${ }^{2,5,6}$ Worldwide, allergic disorders affected up to onethird of the world's populations. ${ }^{7}$ It was estimated, 2014, that 400 million 
persons had allergic rhinitis, 300 million suffered from asthma, and about 200-250 million complained from food allergies. Furthermore, it was estimated that $10 \%$ of the world's people had allergy caused by drugs. Allergy can be associated also with increased economic burden, and results in an annual cost of billions of dollars. ${ }^{8}$ Urbanization and globalization resulted in marked environmental changes, and lead to increased allergens in the environment. ${ }^{9}$

Asthma was ranked as one of the most common chronic diseases in Saudi Arabia. ${ }^{10}$ During college years, allergies may affect students' quality of life by interrupting their daily activities, diminishing faculty attendance, precipitating poor sleep quality, and diminishing the ability to accomplish academic and extra-curricular activities. ${ }^{9}$ A study conducted among 112 medical students from Albaha, Saudi Arabia, revealed a high prevalence of asthma symptoms. ${ }^{11}$

Nowadays, there is an increasing interest in the field of allergy among medical students. ${ }^{12}$ However, there is lack of adequate number of comprehensive epidemiological research done among a large sample of medical students from Jeddah. So, such study is required.The current study was done to determine the prevalence, types, triggers, and predictors of allergic disorders among medical students and interns from King Abdulaziz University (KAU), Jeddah.

\section{METHODS}

A cross-sectional study was conducted between medical student $\left(2^{\text {nd }}-6^{\text {th }}\right.$ year $)$, and interns at KAU during the academic year 2016 / 2017. A multistage stratified random sampling method was used. Stratification took into consideration the gender and the educational level. The sample size was calculated using the formula for estimation of sample size from a cross-sectional study. The prevalence ' $\mathrm{p}$ " $=0.5$, as the most conservative sample due to lack of similar studies from Jeddah. So, $q=1-p=0.5 \& d$ was put at $0.04 \%$. The minimum calculated sample was 600 .

A validated, anonymous, confidential selfadministered questionnaire was used. Face and content validity was done by two experts. Alpha Cronbach's test was done for assessing the internal consistency reliability and was found to be 0.81 .

Information about personal, socio-economic data, habits and chronic diseases were collected. Stress reported during the six months preceding the study, and family history of allergy were also asked. Data about the surrounding environment was assessed. The questionnaire inquired about participant's allergy $(\geq 1)$ according to previous physician's diagnosis. If allergy was present, the type (skin, respiratory, eye, food, and anaphylaxis) was determined. For each type, the specific clinical presentations were also assessed. The participants were also asked about conduction of skin test and its result. They were also inquired about the type of received treatment (if any). Furthermore, the effect of allergy on the students' life was assessed.

Statistical analysis: Data analysis was done using the SPSS version 20. Descriptive and inferential statistics were done. A stepwise multiple logistic regression analysis was done to delineate the predictors of allergic disorders. P-value $<0.05$ was considered statistically significant.

Ethical consideration: The study was approved by the Institutional Review Board (IRB). The study followed the "ethical values of Helsinki declaration". Official approvals were obtained. Each participant wrote an informed written consent.

\section{RESULTS}

The mean age of participants was $22 \pm 1.7$ years, with a male to female ratio of 1:1.05. Prevalence of diagnosed allergic disorders ( $\geq 1$ type) among the participants was $36.2 \%$ as shown in Table-I. Cutaneous $(33.8 \%)$, respiratory $(29.5 \%)$ and eye allergies $(11.2 \%)$ were the most prevalent types. The most frequently reported skin allergy was eczema $(14.3 \%)$. Concerning respiratory allergy, the most prevalent types were nasal congestion \& allergic rhinitis (AR). Asthma was reported by $6.8 \%$ of the participants. The commonest triggering factors of allergy were the house dust (45.6\%), smoke (30.4\%) and cold air $(28.6 \%)$. Table-II.

Females had much higher prevalence of allergy $(43.5 \%)$ compared to males $(28.4 \%)$. Table-III. A highly statistical significant difference was present $\left(X^{2}=14.8, \quad P<0.001\right)$. Participants from families with higher income, and whose fathers obtained a university degree or above reported a higher rate of allergy than others. Smokers had a slightly higher prevalence of allergy compared to others $(P>0.05)$. Furthermore, allergy rate was slightly higher among those exposed to stress, during 6 months preceded the study, compared to others $(P$ $>0.05$ ). Participants with family history of allergic disorders were about 5 times more prone to have allergy compared to others $(\mathrm{OR}=4.7,95 \%$ C.I.: $3.22-$ 6.87). In addition, those who complained of water leaks and molds contamination near their houses had a significantly higher prevalence of allergy than others $\left(X^{2}=3.98, P<0.05\right)$.

First predictor of allergy among medical students and interns was having family history of allergic 
Table-I: Prevalence, clinical types, presentations of the diagnosed allergic disorders among medical students and interns, King Abdulaziz University $(n=600)$.

\begin{tabular}{|c|c|c|}
\hline Type of allergy & No. & $\%$ \\
\hline Any type of allergy $(\geq 1)$ & 217 & 36.2 \\
\hline Skin (cutaneous) allergy & 203 & 33.8 \\
\hline Eczema (atopic eczema) & 86 & 14.3 \\
\hline Contact dermatitis & 54 & 9.0 \\
\hline Itchy rashes & 41 & 6.8 \\
\hline General itching & 36 & 6.0 \\
\hline Hives & 22 & 3.7 \\
\hline $\begin{array}{l}\text { Other symptoms } \\
\text { (swelling, pimply rashes, etc.) }\end{array}$ & 35 & 4.8 \\
\hline $\begin{array}{l}\text { Respiratory or airway allergy } \\
\text { (upper, lower) }\end{array}$ & 177 & 29.5 \\
\hline Nasal congestion & 106 & 17.7 \\
\hline Allergic rhinitis (AR) & 100 & 16.7 \\
\hline Running nose & 83 & 13.8 \\
\hline Asthma & 41 & 6.8 \\
\hline Wheezy chest & 37 & 6.2 \\
\hline Chest tightness & 31 & 5.2 \\
\hline Shortness of breath & 23 & 3.8 \\
\hline Hay fever & 1 & 0.2 \\
\hline $\begin{array}{l}\text { Others (post nasal drips, } \\
\text { itchy nose, sinus allergy) }\end{array}$ & 102 & 17 \\
\hline Ophthalmic allergy & 67 & 11.2 \\
\hline Food allergy & 64 & 10.7 \\
\hline Anaphylaxis & 24 & 4.0 \\
\hline Food & 10 & 1.7 \\
\hline Drug (e.g. penicillin) & 8 & 1.3 \\
\hline Latex (rubber) & 1 & 0.2 \\
\hline Other & 5 & 0.8 \\
\hline
\end{tabular}

N.B. Each question was separately asked.

disorders $(\mathrm{aOR}=4.35,95 \% \mathrm{CI}: 2.96-6.39)$, followed by being a female $(\mathrm{aOR}=1.50,95 \% \mathrm{CI}$ : 1.04-2.15) Table-IV.. Regarding medications, $62.2 \%$ of the participants who had allergy reported receiving drugs. The commonest received treatment were the antihistaminic drugs $(30.4 \%)$, corticosteroids $(11.1 \%)$, bronchodilators $(10.4 \%)$ and decongestants $(8.1 \%)$. In addition, $40.0 \%$ of them used more than one treatment modalities (anti-histaminic, cortisone, decongestants, immunotherapy, etc). Those who used cortisone in any form (either separate or in combinations) accounted for $31.9 \%$. Regarding the source of medications, $41.5 \%$ of the students with allergy used over the counter (OTC) drugs. In addition, 3.0\% of them attended hospital for receiving oxygen, and $6.2 \%$ had never admitted to hospital for allergy. Regarding outcome of allergy, $16.1 \%$ of students with allergy reported missing their classes due to it, and $28.6 \%$ complained from sleep disturbance during allergic attacks.
Table-II: Frequencies of different triggering allergens among medical students \& interns with allergic disorders at King Abdulaziz University $(\mathrm{n}=217)$.

\begin{tabular}{lcc}
\hline Triggering allergens & No & $\%$ \\
\hline House dust & 99 & 45.6 \\
Smoke & 66 & 30.4 \\
Cold air & 62 & 28.6 \\
Perfumes & 58 & 26.7 \\
Weather changes & 58 & 26.7 \\
Pollution & 51 & 23.5 \\
Cats & 45 & 20.7 \\
Odours & 42 & 19.4 \\
Grass & 29 & 13.4 \\
Formalin & 28 & 12.9 \\
Stress & 27 & 12.4 \\
Insecticides & 26 & 11.9 \\
Hay & 21 & 9.7 \\
Pets (dogs) & 21 & 9.7 \\
Humidity & 21 & 9.7 \\
Cosmetics & 19 & 8.8 \\
Mould \& mildew & 19 & 8.8 \\
Exercise & 17 & 6.5 \\
Leaves & 14 & 6.4 \\
Basement floors & 13 & 5.9 \\
Latex & 10 & 4.6 \\
Milk/ dairy products & 9 & 4.1 \\
Menstruation & 5.7 \\
(females with allergy. 134$)$ & & \\
\hline NB: Each question was separately asked & &
\end{tabular}

NB: Each question was separately asked.

Among the participants diagnosed with allergy, only $30(13.8 \%)$ conducted skin-prick test. Results found that the most common separate specific IgE (sIgE) allergens was related to foods as shrimps (8 cases; $26.7 \%$ ), insects (4 cases; $13.3 \%$ ), pet dander (4 cases; 13.3\%), dust mites (3 cases; 10.0\%) and moulds ( 3 cases; $10.0 \%$ ). Furthermore, in $26.7 \%$ of the tested cases had a poly-sensitization to more than one allergens.

\section{DISCUSSION}

The overall prevalence of allergy among our participants was $36.2 \%$, which agrees with results of nine cohorts among third year medical students from Zurich, Switzerland, ${ }^{1}$ and with results among Turkish adolescents and adults. ${ }^{6}$ However, our rate is higher than rates reported between Polish female university students (2009 \& 2015). ${ }^{2}$ This discrepancy may be due to differences between countries, populations, or time of studies. Increase environmental allergens of indoor and outdoor pollution \&decreased biodiversity may contribute to the high allergy prevalence nowadays. ${ }^{2}$ 
Table-III: Relationship between presence of allergy and the study variables among medical students and interns at King Abdulaziz University.

\begin{tabular}{|c|c|c|c|c|c|c|c|}
\hline \multirow{2}{*}{ Variable } & \multicolumn{2}{|c|}{ Allergy $(n=217)$} & \multicolumn{2}{|c|}{ No allergy $(n=383)$} & \multirow{2}{*}{$X^{2}$} & \multirow{2}{*}{$(p)$} & \multirow{2}{*}{$\begin{array}{l}\text { OR } \\
(C I)\end{array}$} \\
\hline & No. & $\%$ & No. & $\%$ & & & \\
\hline $\begin{array}{l}\text { Gender } \\
\text { Female } \\
\text { Male }\end{array}$ & $\begin{array}{c}134 \\
83\end{array}$ & $\begin{array}{l}43.5 \\
28.5\end{array}$ & $\begin{array}{l}174 \\
209\end{array}$ & $\begin{array}{l}56.5 \\
71.6\end{array}$ & 14.8 & $(0.000)$ & $\begin{array}{c}1.93 \\
(1.38-2.72)\end{array}$ \\
\hline $\begin{array}{l}\text { Marital status } \\
\text { Single } \\
\text { Married }\end{array}$ & $\begin{array}{c}202 \\
15\end{array}$ & $\begin{array}{l}35.9 \\
40.5\end{array}$ & $\begin{array}{c}361 \\
22\end{array}$ & $\begin{array}{l}64.1 \\
59.5\end{array}$ & 0.3 & $(0.57)$ & $\begin{array}{c}0.82 \\
(0.42-1.62)\end{array}$ \\
\hline $\begin{array}{l}\text { Educational level: } \\
\text { Basic } \\
\text { Clinical \& interns }\end{array}$ & $\begin{array}{c}59 \\
158\end{array}$ & $\begin{array}{l}35.8 \\
36.3\end{array}$ & $\begin{array}{l}106 \\
277\end{array}$ & $\begin{array}{l}64.2 \\
63.7\end{array}$ & 0.02 & $(0.90)$ & $\begin{array}{c}0.98 \\
(0.67-1.42)\end{array}$ \\
\hline $\begin{array}{l}\text { Father education } \\
\text { University or above } \\
\text { Less than university }\end{array}$ & $\begin{array}{c}175 \\
42\end{array}$ & $\begin{array}{l}38.3 \\
29.4\end{array}$ & $\begin{array}{l}282 \\
101\end{array}$ & $\begin{array}{l}61.7 \\
70.6\end{array}$ & 3.76 & 0.049 & $\begin{array}{c}1.62 \\
(1.07-2.46)\end{array}$ \\
\hline $\begin{array}{l}\text { Mother education } \\
\text { University or above } \\
\text { Less than university }\end{array}$ & $\begin{array}{c}134 \\
78\end{array}$ & $\begin{array}{l}35.6 \\
34.8\end{array}$ & $\begin{array}{l}242 \\
146\end{array}$ & $\begin{array}{l}64.4 \\
65.2\end{array}$ & 0.04 & $(0.84)$ & $\begin{array}{c}1.04 \\
(0.73-1.47)\end{array}$ \\
\hline $\begin{array}{l}\text { Father Occupation } \\
\text { Professional } \\
\text { Non-professional }\end{array}$ & $\begin{array}{c}159 \\
58\end{array}$ & $\begin{array}{l}38.8 \\
34.5\end{array}$ & $\begin{array}{l}273 \\
110\end{array}$ & $\begin{array}{l}63.2 \\
65.5\end{array}$ & 0.27 & $(0.6)$ & $\begin{array}{c}1.11 \\
(0.78-1.65)\end{array}$ \\
\hline $\begin{array}{l}\text { Mother occupation } \\
\text { Professional } \\
\text { Non-professional }\end{array}$ & $\begin{array}{c}96 \\
121\end{array}$ & $\begin{array}{l}36.8 \\
35.7\end{array}$ & $\begin{array}{l}165 \\
222\end{array}$ & $\begin{array}{l}63.2 \\
64.3\end{array}$ & 0.07 & $(0.78)$ & $\begin{array}{c}1.05 \\
(0.75-1.47)\end{array}$ \\
\hline $\begin{array}{l}\text { Father income } \\
\text { Not enough, Enough } \\
\text { Enough and exceed }\end{array}$ & $\begin{array}{c}213 \\
4\end{array}$ & $\begin{array}{l}36.5 \\
23.5\end{array}$ & $\begin{array}{c}370 \\
13\end{array}$ & $\begin{array}{l}63.5 \\
76.5\end{array}$ & $\begin{array}{c}1.21^{\mathrm{a}} \\
\text { (Fisher's } \\
\text { exact test) }\end{array}$ & $(0.27)$ & $\begin{array}{c}1.87 \\
(0.60-5.81)\end{array}$ \\
\hline $\begin{array}{l}\text { Current smoker } \\
\text { Yes } \\
\text { No }\end{array}$ & $\begin{array}{c}29 \\
188\end{array}$ & $\begin{array}{l}39.2 \\
35.7\end{array}$ & $\begin{array}{c}45 \\
338\end{array}$ & $\begin{array}{l}60.8 \\
64.3\end{array}$ & 0.34 & $(0.56)$ & $\begin{array}{c}1.16 \\
(0.70-1.91)\end{array}$ \\
\hline $\begin{array}{l}\text { Passive smoker } \\
\text { Yes } \\
\text { No }\end{array}$ & $\begin{array}{c}113 \\
99\end{array}$ & $\begin{array}{l}36.0 \\
34.6\end{array}$ & $\begin{array}{l}201 \\
187\end{array}$ & $\begin{array}{l}64.0 \\
65.4\end{array}$ & 0.12 & $(0.73)$ & $\begin{array}{c}1.06 \\
(0.76-1.49)\end{array}$ \\
\hline $\begin{array}{l}\text { Stress } \\
\text { Yes } \\
\text { No }\end{array}$ & $\begin{array}{c}29 \\
188\end{array}$ & $\begin{array}{l}39.2 \\
35.7\end{array}$ & $\begin{array}{c}45 \\
338\end{array}$ & $\begin{array}{l}60.8 \\
64.3\end{array}$ & 3.3 & $(0.07)$ & $\begin{array}{c}1.41 \\
(0.97-2.05)\end{array}$ \\
\hline $\begin{array}{l}\text { Family history of alle } \\
\text { Yes } \\
\text { No }\end{array}$ & $\begin{array}{c}169 \\
48\end{array}$ & $\begin{array}{l}50.8 \\
18.0\end{array}$ & $\begin{array}{l}164 \\
219\end{array}$ & $\begin{array}{l}49.2 \\
82.0\end{array}$ & 68.9 & $(0.000)$ & $\begin{array}{c}4.70 \\
(3.22-6.87)\end{array}$ \\
\hline $\begin{array}{l}\text { Wood/Coal Stove } \\
\text { Yes } \\
\text { No }\end{array}$ & $\begin{array}{c}43 \\
169\end{array}$ & $\begin{array}{l}35.8 \\
35.2\end{array}$ & $\begin{array}{c}77 \\
311\end{array}$ & $\begin{array}{l}64.2 \\
64.8\end{array}$ & 0.02 & $(0.90)$ & $\begin{array}{c}1.03 \\
(0.68-1.56)\end{array}$ \\
\hline $\begin{array}{l}\text { Water leaks \& molds } \\
\text { contamination } \\
\text { Yes } \\
\text { No }\end{array}$ & $\begin{array}{c}25 \\
192\end{array}$ & $\begin{array}{l}49.1 \\
34.9\end{array}$ & $\begin{array}{c}26 \\
357\end{array}$ & $\begin{array}{l}50.9 \\
65.1\end{array}$ & 3.98 & $(0.04)$ & $\begin{array}{c}1.79 \\
(1.01-3.182)\end{array}$ \\
\hline
\end{tabular}

a Fisher's exact test.

Prevalence of allergy among our females is more than males, which agrees with results from Ajman, UAE. ${ }^{9}$ Estrogens endogenous female sex hormone may support allergic reactivity by working through estrogen receptor- $\alpha$ of mast cells. ${ }^{13}$ Our participants from families with better income and paternal education had higher prevalence of allergy than others. This may be because prevalence of $\operatorname{IgE}$ 
Table-IV: Predictors of allergic disorders among medical students and interns at King Abdulaziz University.

\begin{tabular}{lcccc}
\hline Variable & $B$ & $P$ & $a O R$ & $95 \%$ C.I. \\
\hline $\begin{array}{l}\text { Family history } \\
\quad 1.471\end{array}$ & 0.000 & 4.35 & 2.96- 6.39 \\
$\quad \begin{array}{l}\text { of allergy } \\
\text { Gender (Female) }\end{array}$ & 0.402 & 0.030 & 1.50 & $1.04-2.15$ \\
Constant & -1.656 & & & \\
\hline
\end{tabular}

sensitization to aeroallergens is increased among persons with high salaries. ${ }^{3}$

Our study found that family history of allergy was the first predictor of allergy among participants, which agrees with other studies. ${ }^{9,14}$ This could be one evidence of the inheritance in allergy. These findings agree with the possible genetic effect in of allergy among family members ${ }^{9}$ and with the recent genetic researches which identified many genetic loci at different Interleukin (IL) "IL1RL1IL18R1, HLA-DQ, IL33, SMAD3, ORMDL3 GSDMB \& IL2RB" and these are found to be related to allergic disorders. ${ }^{15}$

The skin is one of the largest immunologic organs that is affected by both external and internal factors, as well as by innate and adaptive immune responses. ${ }^{16}$ Our study also revealed that cutaneous allergy was the commonest type allergic disorders. This result coincides with that reported among medical students from Turkey. ${ }^{17}$ Regarding different clinical presentation of allergy, the current study showed that prevalence of eczema (atopic eczema) was $14.3 \%$. Similar rates were reported from Ajman, ${ }^{9}$ and Lebanon. ${ }^{18}$

Regarding respiratory allergy, the prevalence of AR from the current study was $16.7 \%$, which coincides with results from a recent study, 2017, done among adolescents from Korea. ${ }^{19}$ On the other hand, our rate is higher than the rate of AR $(10 \%)$ from household surveys in five Middle East countries; based on physicians' diagnosis. ${ }^{20}$ The cause of such discrepancy may be due to differences between the age of the target populations, or the method of reporting and diagnosis the cases. Similarly, a lower rate of AR (7.0\%) than that of our study was reported from seven Emirates of the UAE. ${ }^{21}$

The prevalence of asthma \& wheezy chest among the participants from the present study were found to be $6.8 \%$ and $6.2 \%$, respectively. Our rate of asthma coincides with a rate $(7.5 \%)$ from South India. ${ }^{4}$ However, a lower rate of asthma (4.05\%) was reported from a Saudi household survey done among population aged $\geq 15$ years. ${ }^{22}$ The cause of this discrepancy may be due to differences between the age group and the types of the target populations.
Food allergy occurred among about one-tenth of medical students and interns in the current study. However, a higher rate $(17 \%)$ was reported from Albaha university, ${ }^{11}$ and this difference may be due to differences between the target populations. Concerning ophthalmic allergy, $11.2 \%$ of our participants complained of it, which is much lower than the rate reported from Ajman. ${ }^{9}$ This may be due to the differences between both countries.

In the present study, drug-induced anaphylaxis (especially that induced by antibiotics) was reported by $1.3 \%$ of the participants. The prevalence of drug hypersensitivity reported among medical students from Turkey was $4.7 \% .{ }^{17}$ The cause of lower rate from the current study may be because we inquired about anaphylaxis not all types of hypersensitivity. Regarding allergenic triggers, house dust was the most common trigger in the present study, which agrees with the results from Albaha ${ }^{11}$, Ajman', South India ${ }^{4}$ and from the seven Emirates of UAE. ${ }^{21}$ House dust mite was one of commonest reported allergens between Swiss medical students. ${ }^{1}$ Urbanization have altered the housing conditions due to soft furnishings, closefitting carpets, central air-conditions, and decreased indoor ventilation. Great increase in indoor pollution and allergens can lead to elevation of rates of allergy. ${ }^{9}$

Among our participants, smoke (30.4\%) and perfumes $(26.7 \%)$ were among the most frequently reported allergy triggers (following house dust). Similarly, a study from France, $2017^{23}$, concluded that the same allergens triggers were among the commonest asthmatic triggers.

Stress was reported as triggering factor of allergy in the present study, and the stressed students reported a higher rate of allergy compared to others. Stress can trigger allergy by causing inflammation via modulating immune function by both neural and hormonal mechanisms. ${ }^{23}$ Our results found that the commonest sIgE positivity was for foods as shrimps, which concurs with a study from China, 2017. ${ }^{24}$

The effect of allergies on life, and the extent to which it may restrict the daily activities are often ignored. ${ }^{9}$ In the present study, $16.1 \%$ of the participants who complained of allergy reported that they missed classes, and $28.6 \%$ of them complained of sleep disturbance during allergic attacks. The study of Ajman ${ }^{9}$ also reported that allergy lead to interference with students' academic activities and with the social and extracurricular activities.

\section{CONCLUSION}

The prevalence of the diagnosed allergic disorders was high (36.2\%) among medical students and 
interns at KAU. The predictors of allergic disorders were family history of allergy and the female gender. Cutaneous and respiratory were the commonest types of allergies. The most important reported allergenic triggers were house dust, smoke, cold air, and perfumes. Regarding the outcome of allergy, $16.1 \%$ of students with allergy reported missing their classes due to it, and $28.6 \%$ complained from sleep disturbance; during allergy attacks. Detection of allergens is needed for avoiding them. Conduction of awareness campaigns about allergy, triggers and preventive measures are also needed. Screening and management of allergy cases is needed.

\section{Deceleration of Interest: None.}

Grant Support \& Financial Disclosures: There is no fund.

\section{REFERENCES}

1. Steinegger L, Regenass S, Bachmann LM, Probst E, Steiner UC. Atopy and related clinical symptoms among Swiss medical students from 2007 to 2015. Allergy Asthma Clin Immunol. 2018;14:4-7. doi: 10.1186/s13223-018-0230-4.

2. Klis K, Zurawiecka M, Suder A, Teul I, Borowska-Struginska $\mathrm{B}$, Suliga E, et al. Influence of Socioeconomic Factors on SelfReported Prevalence of Allergic Diseases Among Female University Students. Adv Exp Med Biol. 2017;1020:17-24. doi: 10.1007/5584_2017_14.

3. Caraballo L, Zakzuk J, Lee BW, Acevedo N, Soh JY, Sanchez-Borges M, et al. Particularities of allergy in the Tropics. World Allergy Organ J. 2016;9:20 doi: 10.1186/s40413-016-0110-7.

4. Nitin J, Palagani R, Shradha NH, Vaibhav J, Kowshik K, Manoharan $\mathrm{R}$, et al. Prevalence, severity and risk factors of allergic disorders among people in south India. Afr Health Sci. 2016;16(1):201-209. doi: 10.4314/ahs.v16i1.27.

5. Jones RB, Hewson P, Kaminski ER. Referrals to a regional allergy clinic - an eleven year audit. BMC Public Health. 2010;10:790.doi: 10.1186/1471-2458-10-790.

6. Kose S, Mandiracioglu A, Cavdar G, Ulu Y, Senger SS. Prevalence of allergic diseases in Izmir Province, Turkey. Int Forum Allergy Rhinol. 2014;4(3):232-238. doi: 10.1002/alr.21263

7. Dave ND, Xiang L, Rehm KE, Marshall GD. Stress and Allergic Diseases. Immunol Allergy Clin North Am. 2011;31(1):55-68. doi: 10.1002/alr.21263.

8. Pawankar R. Allergic diseases and asthma: a global public health concern and a call to action. World Allergy Organ J. 2014;7(1):12. doi: 10.1186/1939-4551-7-12

9. John LJ, Ahmed S, Anjum F, Kebab M, Mohammed N, Darwich $\mathrm{H}$, et al. Prevalence of Allergies among University Students: A Study from Ajman, United Arab Emirates. ISRN Allergy. 2014;2014:502052. doi: 10.1186/1939-4551-7-12.

10. Al-Moamary MS, Alhaider SA, Al-Hajjaj MS, Al-Ghobain MO, Idrees MM, Zeitouni MO, et al. The Saudi initiative for asthma-2012 update: Guidelines for the diagnosis and management of asthma in adults and children. Ann Thorac Med. 2012;7(4):175-204. doi: 10.4103/1817-1737.102166

11. Assil SM, Alzahrani SA, Alghamdi HA. The prevalence of asthma symptoms and associated factors among medical students in Al-Baha University December 2014. Euro J Pharma Med Res. 2016;3:37-39

12. Scherzer R. A Critical Need: Increasing Interest in the Field of Allergy and Immunology in Medical Students and Residents. Ann Allergy Asthma Immunol. 2018;121(6):657-659. doi: 10.1016/j. anai.2018.09.457.
13. Bonds RS, Midoro-Horiuti T. Estrogen effects in allergy and asthma. Curr Opin Allergy Clin Immunol. 2013;13(1):92-99. doi: 10.1097/ACI.0b013e32835a6dd6.

14. Lee SM, Ahn JS, Noh CS, Lee SW. Prevalence of allergic diseases and risk factors of wheezing in Korean military personnel. J Korean Med Sci. 2011;26(2):201-206.

15. Tamari M, Tanaka S, Hirota T. Genome-Wide Association Studies of Allergic Diseases. Allergol Int. 2013;62(1):21-28.

16. Fonacier LS, Dreskin SC, Leung DY. Allergic skin diseases. J Allergy Clin Immunol. 2010;125(2 Suppl 2):S138-149.

17. Bavbek S, Erkekol FO, Celik GE, Gonullu I, Misirligil Z. Selfreported prevalence of hypersensitivity reactions against drugs among medical students: does awareness cause any difference? Pharmacoepidemiol Drug Saf. 2011;20(2):154-161. doi: 10.1002/ pds.2076.

18. Musharrafieh U, Al-Sahab B, Zaitoun F, El-Hajj MA, Ramadan $\mathrm{F}$, Tamim H. Prevalence of asthma, allergic rhinitis and eczema among Lebanese adolescents. J Asthma. 2009:46(4):382-387.

19. Kim SY, Kim MS, Park B, Kim JH, Choi HG. Allergic rhinitis, atopic dermatitis, and asthma are associated with differences in school performance among Korean adolescents. PLoS One. 2017;12(2):e0171394. doi: 10.1371/journal.pone.0171394.

20. Abdulrahman H, Hadi U, Tarraf H, Gharagozlou M, Kamel M, Soliman A, et al. Nasal allergies in the Middle Eastern population results from the "Allergies in Middle East Survey". Am J Rhinol Allergy. 2012;26(Suppl 1):S3-S23. doi: 10.2500/ajra.2012.26.3836.

21. Mahboub B, Al-Hammadi S, Prakash VP, Sulaiman N, Blaiss MS, Redha AA et al. Prevalence and triggers of allergic rhinitis in the United Arab Emirates. World Allergy Organ J. 2014;7(1):19. doi: 10.2147/jaa.s121276.

22. Moradi-Lakeh M, El Bcheraoui C, Daoud F, Tuffaha M, Kravitz $\mathrm{H}$, Saeedi MA, et al. Prevalence of asthma in Saudi adults: findings from a national household survey, 2013. BMC Pulm Med. 2015;15:77. doi: 10.1186/s12890-015-0080-5.

23. Gautier C, Charpin D. Environmental triggers and avoidance in the management of asthma. J Asthma Allergy. 2017;10:47-56. doi: $10.2147 /$ jaa.s121276.

24. Zeng G, Luo W, Wu Z, Li L, Zheng P, Huang H, et al. A crosssectional observational study on allergen-specific $\operatorname{IgE}$ positivity in a southeast coastal versus a southwest inland region of China. Sci Rep. 2017;7(1):9593-98. doi: 10.1038/s41598-017-10109-3.

\section{Authors' Contribution:}

NKI: Selected the topic, designed the study, analyzed data, writing, editing manuscript \& the corresponding author.

AAA, MMA, AAA, AKT\& KA: Data collection \& entry, helped in statistical analysis and in manuscript writing.

\section{Authors:}

1. Nahla Khamis Ibrahim,

Professor at Community Medicine Department, King Abdulaziz University, Jeddah, Saudi Arabia; Professor at Epidemiology Department, High Institute of Public Health, Alexandria University, Alexandria, Egypt.

2. Abeer Ali Alghamdi,

3. Mayar Majed Almehmadi,

4. Asma Abdulwahed Alzahrani,

5. Asraa Khairallah Turkistani,

Demonstrator of Family and Community Medicine, Umm Al Qura University, Mecca, Saudi Arabia.

6. Khalid Alghamdi, Resident, King Abdulaziz University, Jeddah, Saudi Arabia.

2-4: Medical Intern, King Abdulaziz University, Jeddah, Saudi Arabia. 